\title{
SISTEM PAKAR DETEKSI BAKAT ANAK USIA 4 SAMPAI DENGAN 6 TAHUN MENGGUNAKAN METODE TEOREMA BAYES
}

\author{
'Intan Novasakti, ${ }^{2}$ Dwi Nurul Huda \\ Sekolah Tinggi Teknologi Indonesia, Jurusan Sistem Informasi \\ e-mail :1intannova75@gmail.com,2dwi.nurulhuda@yahoo.com
}

\begin{abstract}
ABSTRAK
Bakat adalah kemampuan bawaan yang merupakan potensi yang masih perlu dikembangkan atau dilatih untuk mencapai suatu kecakapan, pengetahuan, dan keterampilan khusus. Setiap anak memiliki bakat yang berbeda-beda, bakat tersebut sudah dapat dikenali sejak usia dini, namun kebanyakan orang tua atau guru tidak mengenali bakat yang dimiliki anaknya, bahkan beberapa beranggapan bahwa anak yang pintar adalah anak yang unggul dalam bidang akademik saja. Oleh karena itu maka Penulis merancang sistem pakar deteksi bakat anak usia 4 sampai dengan 6 tahun menggunakan metode teorema bayes.

Sistem pakar deteksi bakat anak usia 4 sampai dengan 6 tahun menggunakan metode teorema bayes dirancang untuk mendeteksi bakat yang dimiliki anak, memberikan informasi mengenai bakat tersebut serta cara untuk memaksimalkan bakat anak. Bakat tersebut berdasarkan teori 8 kecerdasan majemuk menurut Howard Gardner, 8 jenis kecerdasan majemuk tersebut yaitu kecerdasan linguistik, logis-matematis, spasial, musikal, kinestetik, naturalis, interpersonal, dan intrapersonal. Metode teorema bayes melakukan perhitungan melalui ciri-ciri yang dipilih oleh pengguna, setiap ciri-ciri tersebut memiliki probabilitas yang diperoleh dari pakar. Sistem pakar ini dibangun menggunakan bahasa pemrograman Visual Basic.Net 2008 dan Microsoft Office Access 2007 sebagai database. Adapun metodologi yang digunakan untuk pengembangan sistem pakar ini adalah metodologi waterfall.

Dari hasil perancangan maka diperoleh sistem pakar yang dapat mendeteksi bakat anak, memberikan informasi dari kecerdasan majemuk dan cara mengembangkannya.
\end{abstract}

Kata kunci : Sistem Pakar, Kecerdasan Majemuk, Teorema Bayes.

\section{PENDAHULUAN}

Bakat adalah kemampuan bawaan yang merupakan potensi yang masih perlu dikembangkan atau dilatih untuk mencapai suatu kecakapan, pengetahuan, dan keterampilan khusus. Bakat anak dapat dilihat sejak usia dini dari aktivitas kesehariannya, misalnya anak yang mempunyai kemampuan musikal maka dapat dilihat dari ciri - cirinya yaitu terlihat menikmati saat mendengarkan musik, mudah mengikuti irama musik, suka bernyanyi, dan sebagainya. Maka peran orang tua sangat penting dalam mengembangkan potensi anak salah satunya dengan 
memberikan perhatian lebih kepada anaknya dengan mengenali bakat anak sehingga dapat mengarahkan anak sesuai dengan bakatnya karena masa anak - anak adalah masa yang tepat untuk menggali potensi diri.

Setiap anak memiliki bakat yang berbeda-beda, bakat tersebut dapat dikenali jika orang tua memperhatikan apa yang dilakukan anak dalam kesehariannya sehingga sejak dini pula orang tua dapat menyadari dan memahami apa bakat yang dimiliki anaknya. Namun kebanyakan orang tua bahkan guru cenderung mengukur kecerdasaan anak dari bidang akademik saja, padahal pada dasarnya semua anak itu cerdas terlepas dari bidang akademik ataupun nonakademik yang mereka kuasai. Tanpa disadari terkadang orang tua mengarahkan anak berdasarkan kehendak mereka tanpa mengetahui apa sebenarnya bakat anak, sehingga membuat anak tidak menunjukkan perkembangan yang signifikan terhadap apa yang dilakukannya. Oleh karena itu, orang tua dan guru seharusnya memahami dan membimbing anak sesuai dengan bakat anak karena jika anak melakukan hal yang dapat mereka kuasai dengan baik maka kemampuan tersebut akan optimal dan menjadi investasi untuk masa depannya.

Berdasarkan permasalahan tersebut untuk membantu orang tua dan guru memahami kecerdasaan yang ada pada anak maka penulis tertarik untuk membuat sistem pakar deteksi bakat anak menggunakan metode Teorema Bayes. Teorema Bayes adalah metode yang dapat digunakan untuk menangani masalah ketidakpastian data menjadi data yang pasti dengan menyertakan presentasenya. Sebuah sistem pakar yang baik harus mampu menangani masalah ketidakpastian data, maka dengan menggunakan metode Teorema Bayes, sistem pakar dapat mengestimasi dan menarik kesimpulan dengan baik. Oleh karena itu dengan adanya sistem pakar ini diharapkan orang tua dan guru dapat mengetahui potensi bakat anak sehingga dapat mengembangan bakat tersebut.

Sistem pakar adalah sistem yang berusaha mengadopsi pengetahuan manusia ke komputer, agar komputer dapat menyelesaikan masalah seperti biasa dilakukan oleh para ahli. Dengan sistem pakar orang awam dapat menyelesaikan masalah yang cukup rumit yang sebenarnya hanya dapat diselesaikan dengan bantuan para ahli. Dalam pengembangan sistem pakar ini penulis mengambil batasan anak usia dini dari usia 4 sampai dengan 6 tahun sebagai objek penelitian, karena usia 4 sampai 6 tahun merupakan rentang usia anak mengalami pertumbuhan dan perkembangan yang pesat. Dengan adanya sistem pakar ini penulis berharap orang tua dan guru dapat dengan mudah mengetahui macam-macam bakat serta mengenali bakat yang dimiliki anak sehingga dapat mengarahkan anak sesuai dengan bakatnya. 


\section{KAJIAN PUSTAKA}

\subsection{Sistem Pakar}

Sistem pakar adalah sistem yang dirancang untuk dapat menirukan keahlian seorang pakar dalam menjawan pertanyaan dan memecahkan suatu masalah. Sistem pakar akan memberikan pemecahan suatu masalah yang didapat dari dialog dengan pengguna. Dengan bantuan Sistem Pakar seseorang yang bukan pakar atau ahli dapat menjawab pertanyaan, menyelesaikan masalah serta mengambil keputusan yang biasanya dilakukan seorang pakar. Secara garis besar, banya manfaat yang dapat diambil dengan adanya sistem pakar, antara lain:

1. Memungkinkan orang awam bisa mengerjakan pekerjaan para ahli;

2. Bisa melakukan proses secara berulang secara otomatis

3. Menyimpan pengetahuan dan keahlian para pakar

4. Meningkatkan output dan produktivitas

5. Meningkatkan kualitas.

6. Mampu mengambil dan melestarikan keahlian para pakar(terutama yang termasuk keahlian langka)

7. Mampu beroperasi dalam lingkungan yang berbahaya

8. Memiliki kemampuan untuk mengakses pengetahuan.

9. Memiliki reliabilitas.

10. Meningkatkan kapabilitas sistem komputer.

11. Memiliki kemampuan untuk bekerja dengan informasi yang tidak lengkap dan mengandung ketidakpastian.

12. Sebagai media pelengkap dalam pelatihan.

13. Meningkatkan kapabilitas dalam penyelesaian masalah.

14. Menghemat waktu dalam pengambilan keputusan.

Beberapan Kekurangan yang ada pada Sistem Pakar, di antaranya:

1. Biaya yang sangat mahal untuk membuat dan memeliharanya.

2. Sulit dikembangkan karena keterbatasan keahlian dan ketersediaan pakar.

3. Sistem pakar tidak $100 \%$ bernilai benar.

\subsection{Bakat}

Bakat adalah kemampuan bawaan yang merupakan potensi yang masih perlu dikembangkan atau dilatih untuk mencapai suatu kecakapan, pengetahuan, dan keterampilan khusus. Misalnya kemampuan berbahasa, bermain musik, melukis, dan lain-lain.

\subsection{Kecerdasan Majemuk}

Teori kecerdasan majemuk pertama kali diungkapkan oleh Gardner. Ia berusaha untuk memperluas lingkup manusia melampaui batas nilai IQ. Gardner menyatakan bahwa kecerdasan lebih berkaitan dengan kapasitas:

1. Memecahkan masalah

2. Menciptakan produk di lingkungan yang kondusif dan alamiah.

Dengan hal ini, Gardner memetakan hidup kemampuan manusia yang luas menjadi delapan kategori yang komprehensif atau "Delapan Kecerdasan Dasar". Pelajari kebiasan anak sehingga bisa tahu bakat-bakatnya. Jenis - jenis kecerdasan majemuk:

1. Kecerdasan Linguistik ( Word Smart ) 
Kecerdasan linguistik merupakan kecerdasan dalam menggunakan bahasa atau kata-kata secara efektif, baik secara lisan maupun tulisan. Kecerdasan ini, antara lain meliputi kemampuan untuk berbicara, menulis, bercerita atau mendengarkan, menganalisa tata bahasa, mengerti kata-kata serta nuansa makna kata, mengingat informasi, dan mampu meyakinkan orang lain akan pendapatnya.

2. Kecerdasan Matematis-Logis (Logic Smart)

Kecerdasan matematis-logis merupakan kecerdasan dalam menggunakan angka-angka dan penalaran (logika). Kecerdasan ini meliputi kemampuan di bidang sains, mengklasifikasikan dan mengkategorikan informasi, berpikir dengan konsep abstrak untuk menemukan hubungan antara suatu hal dengan hal lainnya, serta memecahkan masalah secara logis terutama dalam bidang matematik (memanipulasi angka).

3. Kecerdasan Spasial (Picture Smart)

Kecerdasan ini termasuk kemampuan untuk mengerti diagram dan grafik, membaut sketsa, menulis, melukis, mendesain, dan menginterpretasikan gambar-gambar visual, serta memiliki kepekaan terhadap warna dan garis. Jenis kecerdasan ini sangat menonjol dalam diri pemain catur, navigator, arsitek, atau desainer.

4. Kecerdasan Musikal (Music Smart)

Kecerdasan musik adalah kemampuan untuk menikmati, mengamati, membedakan, mengarang, membentuk, dan mengekspresikan bentuk-bentuk musik. Kecerdasan ini meliputi kepekaan terhadap ritme, melodi, dan timbre dari musik yang didengar.

5. Kecerdasan Kinestetik-Jasmani (Body Smart)

Kecerdasan kinestetik meliputi kemampuan menari, pantonim, olahraga, menggunakan bahasa tubuh, berakting, serta menggunakan tangan untuk menciptakan atau membangun sesuatu. Kecerdasan kinestetik ini pada umumnya telah dapat diamati sejak individu masih anak-anak, yakni dari gerakan mereka saat bermain, berlari, menendang, dan menari.

6. Kecerdasan Naturalis (Nature Smart)

Kecerdasan naturalis merupakan kecerdasan dalam memahami alam yang meliputi kemampuan untuk mengidentifikasi dan mengklasifikasikan perbedaan ataupun persamaan ciri-ciri di antara spesies, baik flora maupun fauna. Misalnya, tumbuh-tumbuhan, binatang, dan lingkungan hidup lain serta mampu berinteraksi secara efektif dengan alam.

7. Kecerdasan Interpersonal (People Smart)

Kecerdasan interpersonal dalah suatu kemampuan untuk masuk ke dalam diri orang lain, mengerti dunia orang lain, mengerti pandangan, sikap, kepribadian, dan karakter orang lain.Mereka yang berhasil mengembangkan kecerdasan ini dengan sangat baik sangat mudah untuk menjadi seorang ahli terapi, konselor, guru, penjual, pembimbing, mentor, dan pembicara publik.

8. Kecerdasan Intrapersonal (Self Smart)

Kecerdasan intrapersonal merupakan kecerdasan dalam mengerti dan memahami diri sendiri. Kecerdasan ini meliputi kemampuan untuk merefleksikan dan menganalisis diri, mengenal baik kekuatan maupun kelemahan yang dimiliki, menyadari perasaan, harapan, keinginan dan 
tujuan yang hendak dicapai, serta mampu untuk memahami peran dirinya dalam berhubungan dengan orang lain.

\subsection{Anak Usia Dini}

Berdasarkan Kamus Besar Bahasa Indoensia, anak diartikan dengan manusia yang masih kecil, yaitu yang baru berumur 6 tahun. Jadi jika diartikan secara bahasa, anak usia dini adalah sebutan bagi anak yang berusia antara $0-$ 6 tahun. Secara normatif, memang anak diartikan sebagai seseorang yang lahir sampai usia 6 tahun.

Kemudian jika ditinjau dari sisi usia kronologisnya, menurut kesepakan UNESCO anak usia dini merupakan kelompok anak yang berada pada rentang usia $0-8$ tahun. Hal ini berbeda dengan pengertian anak usia dini pada Undang - Undang RI No. 20 tahun 2003 tentang Sistem Pendidikan Nasional, pada pasal 1 Ayat 4 dinyatakan bahwa anak usia dini diartikan sebagai anak yang berusia lahir ( 0 tahun ) sampai dengan 8 tahun.

\subsubsection{Perkembangan Anak Usia 4 sampai dengan 6 Tahun}

Anak usia 4-6 tahun merupakan bagian anak usia dini yang berada pada rentangan usia lahir sampai 6 tahun. Pada usia ini secara terminologi disebut sebagai anak usia prasekolah. Taman Kanak-Kanak (TK) merupakan salah satu jenjang pendidikan prasekolah pada jalur pendidikan formal. Anak usia prasekolah antara rentang 4-6 tahun ini, biasanya sedang menempuh jenjang pendidikan formal ini, baik yang diselenggarakan oleh pemerintah (Negeri) ataupun pihak swasta. Pada usia TK (4-6 tahun), merupakan masa peka bagi anak. Anak mulai sensitif untuk menerima berbagai upaya perkembangan seluruh potensi. Masa peka adalah masa terjadinya pematangan fungsi-fungsi fisik dan psikis yang siap merespon stimulasi yang diberikan oleh lingkungan. Masa ini merupakan masa untuk meletakan dasar pertama dalam mengembangkan kemampuan fisik, kognitif, bahasa, sosial emosional, konsep diri, disiplin, kemandirian, seni, moral, dan nilai-nilai agama.

Anak berusia 4 - 6 tahun sudah mampu menciptakan dunianya sendiri, ditandai dengan memberikan ciri makhluk hidup pada bendabenda. Misalnya, beranggapan bahwa jika malam tiba matahari juga tidur seperti dirinya. Mereka mulai memahami kondep bilangan dan bahkan ada beberapa di antara mereka sudah menguasai konsep operasi sederhana, seperti penjumlahan dan pengurangan hingga 10. Keingintahuannya semakin besar, eksperimen dilakukan berdasarkan sebuah konsep dan berpikir berdasarkan argumentasi rasional. Mereka sering kali tampil sebagai anak yang "cerewet" dan haus akan jawaban.

Pada usia 4 - 6 tahun ini anak sudah dapat mengikuti irama lagu dan mengenal baik naik turunnya nada lagu. Latihan mengenal ritme dapat dilakukan misalnya dengan cara bertepuk tangan, memukul meja dengan ritme tertentu, memukul gendang, gerakan tari sederhana bersama-sama

\subsection{Teorema Bayes}

Teorema Bayes adalah pendekatan statistik untuk menghitung trade off diantara keputusan yang berbeda-beda, dengan menggunakan probabilitas dan nilai yang menyertai suatu pengambilan keputusan tersebut. Teorema Bayes adalah metode yang dapat digunakan untuk menangani masalah ketidakpastian 
data menjadi data yang pasti dengan menyertakan presentasenya. Sebuah sistem pakar yang baik harus mampu menangani masalah ketidakpastian data, maka dengan menggunakan metode Teorema Bayes, sistem pakar dapat mengestimasi dan menarik kesimpulan dengan baik.

Berikut ini bentuk Teorema Bayes untuk evidence ganda dan hipotesis ganda

$$
\begin{aligned}
& \mathrm{p}\left(H_{1} \mid E_{1} E_{2} \ldots E_{m}\right)=
\end{aligned}
$$

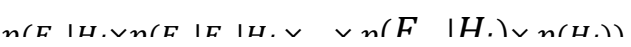

Keterangan:

$\mathrm{p}\left(\mathrm{H}_{\mathrm{i}} \mid \mathrm{E}_{\mathrm{m}}\right)=$ probabilitas hipotesis Hi terjadi jika evidence $\mathrm{E}$ terjadi.

$\mathrm{p}\left(\mathrm{E}_{\mathrm{m}} \mid \mathrm{H}_{\mathrm{i}}\right)=$ probabilitas munculnya evidence $\mathrm{E}$, jika hipotesis Hi terjadi.

$\mathrm{p}\left(\mathrm{H}_{\mathrm{i}}\right)=$ probabilitas hipotesis $\mathrm{Hi}$ tanpa memandang evidence apapun.

$\mathrm{n}=$ jumlah hipotesis yang mungkin

\section{METODOLOGI PENELITIAN}

Merupakan suatu teknik atau cara untuk mengumpulkan data atau fakta yang nantinya akan dipelajari dan digunakan sebagai bahan untuk memudahkan pencarian pemecahan suatu masalah.

\subsection{Metode Pengumpulan Data}

Metode yang digunakan untuk mendapatkan data yang diperlukan sebagai berikut :

\section{Observasi}

Metode pengumpulan data ini dilakukan dengan pengamatan secara langsung bersama pakar terhadap kegiatan sehari - hari anak untuk mendapatkan data yang berkaitan dengan bakat anak.

\section{Wawancara}

Melakukan wawancara kepada pihak - pihak yang terkait dengan sistem sebagai tambahan informasi untuk pengembangan sistem yang dirancang.

3. Studi Kepustakaan

Melakukan pengumpulan data secara tidak langsung dengan melakukan studi kepustakaan, yaitu dengan mengumpulkan data-data dan teori-teori yang berhubungan dengan bakat anak sebagai informasi tambahan dalam pembuatan sistem pakar.

\subsection{Metode PengembanganPerangkat Lunak}

Metode pengembangan perangkat lunak yang digunakan dalam membangun sistem informasi ini menggunakan model Waterfall (Classic Life Cycle) yang menyarankan pengembangan perangkat lunak secara sistematik dan berurutan yang dimulai dari tingkatan sistem tertinggi dan berlanjut ke tahap analisis, desain, pengkodean, pengujian dan pemeliharaan. Kelebihan dari metode ini adalah terstruktur, dinamis, dan sequential. Metode Waterfall dapat di lihat pada gambar 1.1 yang diambil oleh Adi Nugroho dari buku Object Oriented Programming With C++ tulisan Balagurusamy (1999): 


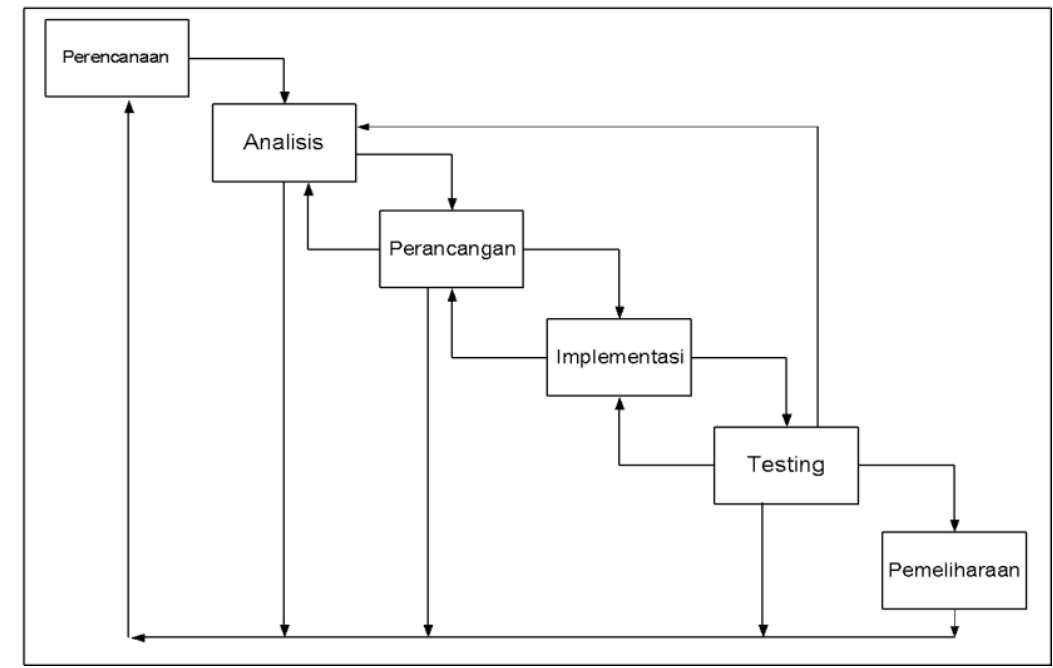

Gambar 1 Diagram Waterfall

Paradigma dari tahapan model waterfall adalah sebagai berikut:

1. Perencanaan, adalah apa yang dijelaskan pada bab ini yaitu menyangkut studi kebutuhan pengguna, studi-studi layakan baik secara teknis maupun secara teknologi serta penjadwalan pengembangan suatu proyek sistem informasi dan atau perangkat lunak.

2. Analisis, yaitu tahap dimana kita berusaha mengenali segenap permasalahan yang muncul pada pengguna dengan mendekomposisi usecase diagram lebih lanjut, mengenali komponen-komponen sistem, obyek-obyek, hubungan antar obyek.

3. Perancangan, dimana kita mencoba mencari solusi permasalahan yang didapat dari tahap analisis. Tahap perancangan menekankan pada platform apa hasil dari tahap analisis kelak akan diimplementasikan.

4. Implementasi, dimana kita mengimplemtasikan perancangan sistem ke situasi yang nyata. Disini kita mulai berurusan dengan pemilihan perangkat keras, penyusunan perangkat lunak aplikasi (pengkodean atau coding).

5. Pengujian, apakah sistem yang kita buat sudah sesuai dengan kebutuhan pengguna atau belum. Jika belum, proses selanjutnya adalah iteratif, yaitu kembali ke tahap-tahap sebelumnya.

6. Pemeliharaan, dimana kita mulai melakukan pengoperasian sistem dan jika di perlukan melakukan perbaikan-perbaikan.

\section{HASIL DAN PEMBAHASAN}

\subsection{Analisis Basis Pengetahuan}

Basis pengetahuan adalah kumpulan fakta beserta aturan-aturan yang digunakan untuk membangun sistem pakar deteksi bakat anak. Berikut basis pengetahuan yang digunakan dalam membangun sistem pakar deteksi bakat anak dimana tipe kecerdasan diambil dari teori dari 8 kecerdasan majemuk yang dikemukakan oleh Howard Gardner yang disajikan dalam tabel tabel kecerdasan majemuk dan ciri-cirinya yang didapatkan dari sumber buku dan pakar

Tabel 1 : Tabel Pasangan Kecerdasan Majemuk dan Ciri-cirinya 


\begin{tabular}{|c|c|c|c|}
\hline No. & $\begin{array}{l}\text { Kecerdasan } \\
\text { Majemuk }\end{array}$ & Ciri-ciri & $\begin{array}{l}\text { Kode } \\
\text { ciri-ciri }\end{array}$ \\
\hline \multirow{6}{*}{1.} & \multirow{6}{*}{$\begin{array}{l}\text { Linguistik } \\
\qquad\left(\mathrm{H}_{1}\right)\end{array}$} & Senang berbicara dengan orang lain. & E01 \\
\hline & & Senang bercerita tentang apa yang ia ketahui dan ia lihat. & E02 \\
\hline & & $\begin{array}{l}\text { Mudah mengingat nama teman dan keluarga, atau hal - hal kecil } \\
\text { yang pernah didengar. }\end{array}$ & E03 \\
\hline & & Suka membawa buku dan pura-pura membacanya. & E04 \\
\hline & & Suka meniru tulisan disekitarnya. & E05 \\
\hline & & $\begin{array}{l}\text { Suka memperhatikan cerita atau pembacaan cerita dan dapat } \\
\text { menceritakan kembali dengan baik. }\end{array}$ & E06 \\
\hline \multirow{6}{*}{2.} & \multirow{6}{*}{$\begin{array}{l}\text { Matematis- } \\
\operatorname{logis}\left(\mathrm{H}_{2}\right)\end{array}$} & Senang melihat angka-angka & E07 \\
\hline & & Cepat menghitung benda yang ia miliki & E08 \\
\hline & & $\begin{array}{l}\text { Suka menekan-nekan kalkulator dan senang melihat angka yang } \\
\text { muncul }\end{array}$ & E09 \\
\hline & & $\begin{array}{l}\text { Senang menyusun balok, memasang puzzle, atau memasangkan } \\
\text { gambar }\end{array}$ & E10 \\
\hline & & $\begin{array}{l}\text { Dapat menata benda-benda berdasarkan urutan ukuran seperti dari } \\
\text { besar hingga kecil atau sebaliknya }\end{array}$ & E11 \\
\hline & & $\begin{array}{l}\text { Dapat menjelaskan sesuatu dengan logis, misalnya ia terjatuh } \\
\text { karena tersandung batu }\end{array}$ & E12 \\
\hline \multirow{5}{*}{3.} & \multirow{5}{*}{ Spasial $\left(\mathrm{H}_{3}\right)$} & Dapat menggambar dengan baik dibandingkan anak seusianya & E13 \\
\hline & & $\begin{array}{l}\text { Cepat mengenali warna-warna, atau dapat memadukan warna pada } \\
\text { gambar-gambar dibuku dengan baik }\end{array}$ & E14 \\
\hline & & Suka melihat buku-buku bergambar & E15 \\
\hline & & Cepat mengenali orang - orang dalam foto & E16 \\
\hline & & $\begin{array}{l}\text { Senang memperhatikan letak benda disekitar dan menghafal } \\
\text { letaknya }\end{array}$ & E17 \\
\hline \multirow{5}{*}{4.} & \multirow{5}{*}{ Musikal $\left(\mathrm{H}_{4}\right)$} & Dapat menyanyi lebih baik dibanding anak seusianya & E18 \\
\hline & & Suka memukul benda-benda sekitar misalnya meja dan pintu & E19 \\
\hline & & Mudah menghafalkan lagu-lagu & E20 \\
\hline & & Dapat menebak lagu dengan cepat jika hanya diberi beberapa nada & E21 \\
\hline & & Mudah mengikuti irama musik & E22 \\
\hline
\end{tabular}




\begin{tabular}{|c|c|c|c|}
\hline & & Bisa menilai jika lagu dinyanyikan dengan nada yang salah & E23 \\
\hline \multirow{5}{*}{5 . } & \multirow{5}{*}{$\begin{array}{l}\text { Kinestetik } \\
\qquad\left(\mathrm{H}_{5}\right)\end{array}$} & Tidak bisa diam atau senang bergerak dan lincah & E24 \\
\hline & & Sering keluar masuk kelas,dan berjalan-jalan dikelas & E25 \\
\hline & & $\begin{array}{l}\text { Suka menyentuh benda yang dilihatnya seperti menekan tombol- } \\
\text { tombol }\end{array}$ & E26 \\
\hline & & Dapat menirukan gerakan orang lain dengan mudah & E27 \\
\hline & & $\begin{array}{l}\text { Dapat beraktifitas fisik dengan baik seperti melompat, berlari, atau } \\
\text { menendang bola }\end{array}$ & E28 \\
\hline \multirow{6}{*}{6.} & \multirow{6}{*}{ Naturalis $\left(\mathrm{H}_{6}\right)$} & Lebih banyak diluar kelas, atau senang mendekat kejendela & E29 \\
\hline & & Suka melihat binatang & E30 \\
\hline & & Tidak takut terhadap binatang & E31 \\
\hline & & Senang bermain dikebun binatang & E32 \\
\hline & & $\begin{array}{l}\text { Tertarik saat melihat gambar binatang dan tumbuhan bahkan } \\
\text { mengamatinya }\end{array}$ & E33 \\
\hline & & Senang bertanya nama-nama bunga, dan nama-nama binatang & E34 \\
\hline \multirow{4}{*}{7.} & \multirow{4}{*}{$\begin{array}{c}\text { Interpersonal } \\
\left(\mathrm{H}_{7}\right)\end{array}$} & $\begin{array}{l}\text { Mudah berteman sehingga memiliki banyak teman dari pada anak } \\
\text { yang lain }\end{array}$ & E35 \\
\hline & & Tidak takut dengan orang baru & E36 \\
\hline & & Ramah dengan orang sekitar & E37 \\
\hline & & Tidak malu-malu saat berbicara dengan teman atau orang dewasa & E38 \\
\hline \multirow{4}{*}{8.} & \multirow{4}{*}{$\begin{array}{c}\text { Intrapersonal } \\
\left(\mathrm{H}_{8}\right)\end{array}$} & Terlihat lebih pendiam dibandingkan teman seusianya & E39 \\
\hline & & Memiliki benda yang tidak suka diganggu orang lain & $\mathrm{E} 40$ \\
\hline & & Lebih menikmati saat bermain sendiri & E41 \\
\hline & & Senang melakukan sesuatu sendiri & E42 \\
\hline
\end{tabular}

Tabel 2 : Probabilitas Kecerdasan Majemuk

\begin{tabular}{|c|c|l|c|c|}
\hline No. & Kode & \multicolumn{1}{|c|}{ Tipe Kecerdasan } & Jumlah ciri-ciri & $\begin{array}{c}\text { Probabilitas Kejadian Tanpa } \\
\text { Melihat Kriteria } \mathrm{p}(\mathrm{H})\end{array}$ \\
\hline 1. & $\mathrm{H}_{1}$ & Linguistik & 6 & 0,14 \\
\hline 2. & $\mathrm{H}_{2}$ & Matematis-Logis & 6 & 0,14 \\
\hline
\end{tabular}




\begin{tabular}{|c|c|l|c|c|}
\hline 3. & $\mathrm{H}_{3}$ & Spasial & 5 & 0,12 \\
\hline 4. & $\mathrm{H}_{4}$ & Musikal & 6 & 0,14 \\
\hline 5. & $\mathrm{H}_{5}$ & Kinestetik & 5 & 0,12 \\
\hline 6. & $\mathrm{H}_{6}$ & Naturalis & 6 & 0,14 \\
\hline 7. & $\mathrm{H}_{7}$ & Interpersonal & 4 & 0,09 \\
\hline 8. & $\mathrm{H}_{8}$ & Intrapersonal & 4 & 0,09 \\
\hline
\end{tabular}

Dari hasil analisa pakar maka didapatkan tabel probabilitas ciri-ciri setiap kecerdasan majemuk sebagai berikut :

Tabel 3 : Tabel Probabilitas Ciri-ciri

\begin{tabular}{|c|c|c|c|c|c|c|c|c|}
\hline $\begin{array}{c}\text { Kode } \\
\text { Ciri-ciri }\end{array}$ & Linguistik & $\begin{array}{c}\text { Matematis- } \\
\text { Logis }\end{array}$ & Spasial & Musikal & $\begin{array}{c}\text { Kines } \\
\text { tetik }\end{array}$ & Naturalis & $\begin{array}{c}\text { Inter- } \\
\text { personal }\end{array}$ & $\begin{array}{c}\text { Intra- } \\
\text { Personal }\end{array}$ \\
\hline E01 & 0,9 & 0,2 & 0,05 & 0,2 & 0,05 & 0,1 & 0,5 & 0,1 \\
\hline E02 & 0,9 & 0,2 & 0,2 & 0,05 & 0,05 & 0,2 & 0,2 & 0,1 \\
\hline E03 & 0,9 & 0,2 & 0,05 & 0,2 & 0,05 & 0,1 & 0,3 & 0,3 \\
\hline E04 & 0,8 & 0,2 & 0,1 & 0,1 & 0,1 & 0,1 & 0,1 & 0,1 \\
\hline E05 & 0,8 & 0,1 & 0,2 & 0,1 & 0,1 & 0,1 & 0,1 & 0,1 \\
\hline E06 & 0,95 & 0,2 & 0,2 & 0,1 & 0,1 & 0,1 & 0,3 & 0,24 \\
\hline E07 & 0,2 & 0,8 & 0,1 & 0,05 & 0,05 & 0,05 & 0,05 & 0,05 \\
\hline E08 & 0,2 & 0,9 & 0,1 & 0,1 & 0,2 & 0,1 & 0,1 & 0,1 \\
\hline E09 & 0,3 & 0,8 & 0,2 & 0,05 & 0,2 & 0,05 & 0,05 & 0,05 \\
\hline E10 & 0,1 & 0,85 & 0,3 & 0,1 & 0,2 & 0,1 & 0,1 & 0,1 \\
\hline E11 & 0,05 & 0,9 & 0,2 & 0,1 & 0,2 & 0,1 & 0,1 & 0,1 \\
\hline E12 & 0,2 & 0,9 & 0,1 & 0,05 & 0,1 & 0,1 & 0,2 & 0,3 \\
\hline E13 & 0,1 & 0,1 & 0,9 & 0,2 & 0,3 & 0,2 & 0,1 & 0,1 \\
\hline E14 & 0,15 & 0,1 & 0,95 & 0,1 & 0,1 & 0,2 & 0,2 & 0,2 \\
\hline E15 & 0,05 & 0,15 & 0,8 & 0,1 & 0,2 & 0,4 & 0,1 & 0,2 \\
\hline E16 & 0,3 & 0,1 & 0,8 & 0,2 & 0,1 & 0,2 & 0,2 & 0,2 \\
\hline E17 & 0,1 & 0,2 & 0,9 & 0,1 & 0,2 & 0,3 & 0,2 & 0,2 \\
\hline E18 & 0,05 & 0,1 & 0,1 & 0,9 & 0,1 & 0,1 & 0,1 & 0,1 \\
\hline E19 & 0,1 & 0,05 & 0,05 & 0,8 & 0,4 & 0,1 & 0,1 & 0,1 \\
\hline E20 & 0,4 & 0,2 & 0,1 & 0,9 & 0,05 & 0,05 & 0,1 & 0,05 \\
\hline E21 & 0,1 & 0,2 & 0,1 & 0,9 & 0,2 & 0,2 & 0,2 & 0,2 \\
\hline E22 & 0,1 & 0,1 & 0,1 & 0,9 & 0,1 & 0,1 & 0,1 & 0,1 \\
\hline E23 & 0,1 & 0,1 & 0,1 & 0,9 & 0,1 & 0,1 & 0,1 & 0,1 \\
\hline E24 & 0,2 & 0,05 & 0,05 & 0,2 & 0,85 & 0,3 & 0,2 & 0,1 \\
\hline E25 & 0,2 & 0,1 & 0,2 & 0,1 & 0,8 & 0,4 & 0,2 & 0,2 \\
\hline E26 & 0,1 & 0,3 & 0,2 & 0,1 & 0,75 & 0,2 & 0,2 & 0,2 \\
\hline E27 & 0,05 & 0,05 & 0,15 & 0,15 & 0,9 & 0,2 & 0,1 & 0,1 \\
\hline E28 & 0,1 & 0,05 & 0,1 & 0,1 & 0,95 & 0,1 & 0,1 & 0,1 \\
\hline E29 & 0,1 & 0,2 & 0,2 & 0,2 & 0,45 & 0,8 & 0,25 & 0,2 \\
\hline E30 & 0,05 & 0,1 & 0,2 & 0,05 & 0,2 & 0,9 & 0,2 & 0,2 \\
\hline E31 & 0,05 & 0,1 & 0,1 & 0,1 & 0,1 & 0,95 & 0,1 & 0,1 \\
\hline E32 & 0,2 & 0,2 & 0,2 & 0,2 & 0,4 & 0,9 & 0,2 & 0,2 \\
\hline E33 & 0,1 & 0,1 & 0,3 & 0,1 & 0,2 & 0,8 & 0,1 & 0,2 \\
\hline & & & & & & & & \\
\hline
\end{tabular}




\begin{tabular}{|c|c|c|c|c|c|c|c|c|} 
E34 & 0,4 & 0,2 & 0,2 & 0,1 & 0,1 & 0,85 & 0,2 & 0,2 \\
\hline E35 & 0,4 & 0,2 & 0,1 & 0,2 & 0,2 & 0,2 & 0,8 & 0,1 \\
\hline E36 & 0,2 & 0,2 & 0,1 & 0,1 & 0,1 & 0,2 & 0,9 & 0,2 \\
\hline E37 & 0,3 & 0,1 & 0,2 & 0,2 & 0,1 & 0,1 & 0,9 & 0,1 \\
\hline E38 & 0,3 & 0,2 & 0,2 & 0,2 & 0,2 & 0,2 & 0,9 & 0,2 \\
\hline E39 & 0,05 & 0,2 & 0,1 & 0,05 & 0,1 & 0,1 & 0,05 & 0,8 \\
\hline E40 & 0,2 & 0,2 & 0,2 & 0,1 & 0,1 & 0,1 & 0,2 & 0,9 \\
\hline E41 & 0,1 & 0,2 & 0,2 & 0,05 & 0,1 & 0,25 & 0,05 & 0,9 \\
\hline E42 & 0,05 & 0,15 & 0,15 & 0,1 & 0,1 & 0,2 & 0,1 & 0,95 \\
\hline
\end{tabular}

Berikut perhitungan dalam menentukan bakat anak menggunakan metode teorema bayes jika diketahui ciri-ciri anak sebagai berikut:

1. Senang berbicara dengan orang lain

2. Senang bercerita tentang apa yang ia ketahui dan ia lihat

3. Dapat menjelaskan sesuatu dengan logis, misalnya ia terjatuh karena tersandung batu

4. Cepat mengenali warna-warna atau dapat memadukan warna pada gambargambar dibuku dengan baik

5. Dapat menyanyi lebih baik dibanding anak seusianya

6. Mudah menghafalkan lagu-lagu

Berdasarkan ciri-ciri tersebut maka dalam menentukan bakat anak tersebut dapat dihitung menggunakan bentuk teorema bayes hipotesis ganda dan evidence ganda dengan cara:

$$
\begin{aligned}
& \mathrm{p}\left(H_{1} \mid E_{1} E_{2} \ldots E_{m}\right)=\frac{p\left(E_{1} \mid H_{i} \times p\left(E_{2} \mid H_{i} \times \ldots \times p\left(E_{m} \mid H_{i}\right) \times p H_{i}\right)\right.}{\sum_{k=1}^{n} p\left(E_{1} \mid H_{k}\right) \times p\left(E_{2} \mid H_{k}\right) \times \ldots \times p\left(E_{m} \mid H_{k}\right) \times p\left(H_{k}\right)} \\
& \mathrm{p}\left(H_{1} \mid E_{1} E_{2} E_{12} E_{14} E_{18} E_{20}\right)=\frac{0,9 \times 0,9 \times 0,2 \times 0,15 \times 0,5 \times 0,4 \times 0,14}{0,000701415}=0,760350897 \\
& \mathrm{p}\left(H_{2} \mid E_{1} E_{2} E_{12} E_{14} E_{18} E_{20}\right)=\frac{0,2 \times 0,2 \times 0,9 \times 0,1 \times 0,1 \times 0,2 \times 0,14}{0,000701415}=0,112644577 \\
& \mathrm{p}\left(H_{3} \mid E_{1} E_{2} E_{12} E_{14} E_{18} E_{20}\right)=\frac{0,05 \times 0,2 \times 0,1 \times 0,95 \times 0,1 \times 0,1 \times 0,12}{0,000701415}=0,012739565 \\
& \mathrm{p}\left(H_{4} \mid E_{1} E_{2} E_{12} E_{14} E_{18} E_{20}\right)=\frac{0,2 \times 0,05 \times 0,05 \times 0,1 \times 0,9 \times 0,9 \times 0,14}{0,000701415}=0,063362575 \\
& \mathrm{p}\left(H_{5} \mid E_{1} E_{2} E_{12} E_{14} E_{18} E_{20}\right)=\frac{0,05 \times 0,05 \times 0,1 \times 0,1 \times 0,1 \times 0,05 \times 0,12}{0,000701415}=0,000167626 \\
& \mathrm{p}\left(H_{6} \mid E_{1} E_{2} E_{12} E_{14} E_{18} E_{20}\right)=\frac{0,1 \times 0,2 \times 0,1 \times 0,2 \times 0,1 \times 0,05 \times 0,12}{0,000701415}=0,002682014 \\
& \mathrm{p}\left(H_{7} \mid E_{1} E_{2} E_{12} E_{14} E_{18} E_{20}\right)=\frac{0,5 \times 0,2 \times 0,2 \times 0,2 \times 0,1 \times 0,1 \times 0,09}{0,000701415}=0,044700229 \\
& \mathrm{p}\left(H_{8} \mid E_{1} E_{2} E_{12} E_{14} E_{18} E_{20}\right)=\frac{0,1 \times 0,1 \times 0,3 \times 0,2 \times 0,1 \times 0,05 \times 0,09}{0,000701415}=0,003352517
\end{aligned}
$$

Berdasarkan perhitungan diatas maka dapat disimpulkan bahwa anak berbakat dalam bidang Linguistik dengan tingkat kepercayaan sebesar $0,760350897 \times$ $100 \%=76,0350897 \%$.

\subsection{Perancangan}

Perancangan sistem merupakan tahapan yang dilakukan setelah analisa sistem. Perancangan sistem adalah strategi untuk memecahkan masalah dan mengembangkan solusi terbaik bagi permasalahan itu. Perancangan sistem adalah termasuk bagaimana mengorganisasi sistem ke dalam subsistem- 
subsistem, serta alokasi subsistem-subsistem ke komponen-komponen perangkat keras, perangkat lunak serta prosedur-prosedur.

\subsubsection{Use Case Diagram}

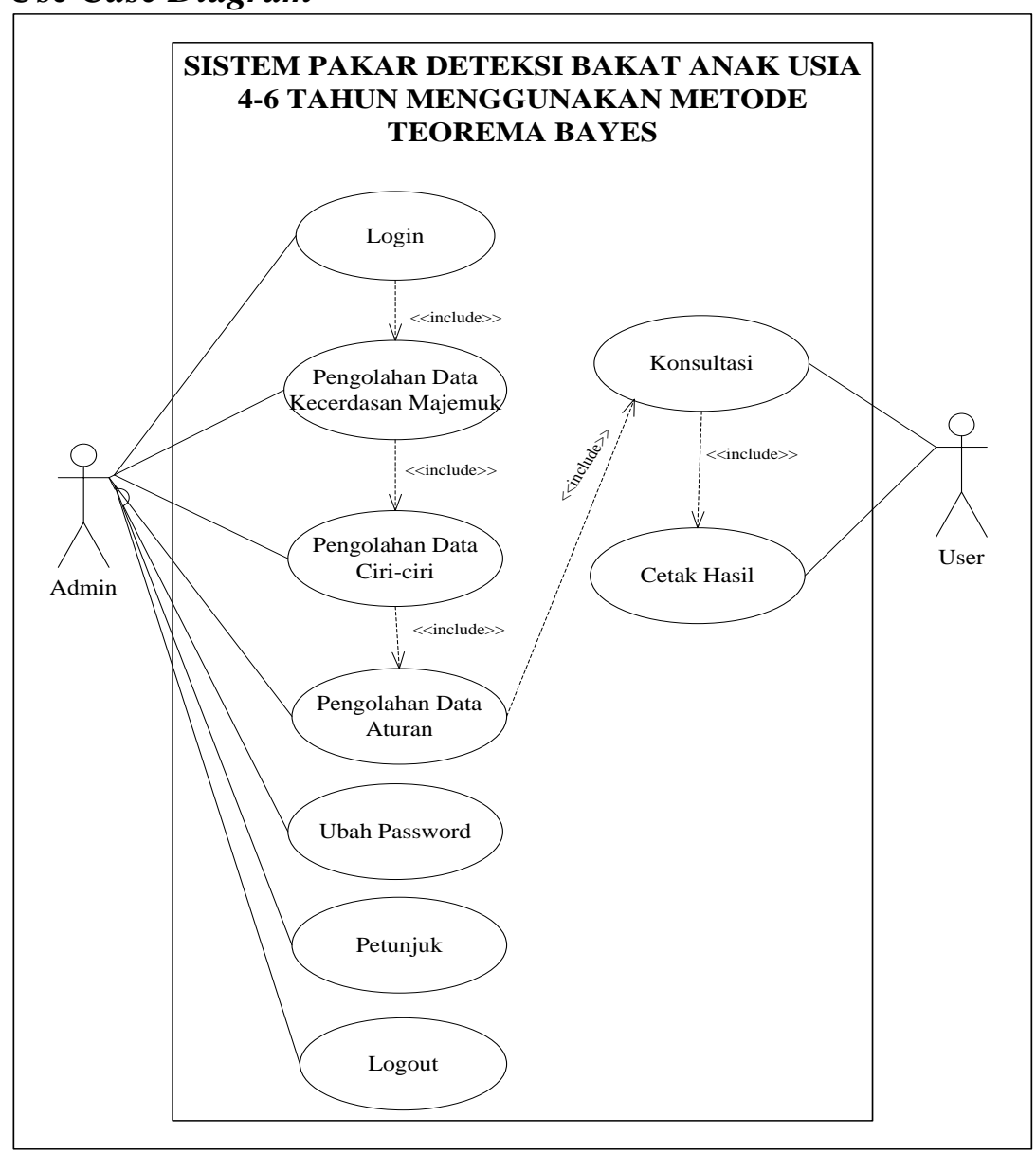

Gambar 2 Use Case Diagram

\subsubsection{Perancangan Antarmuka Form Deteksi Bakat Anak}

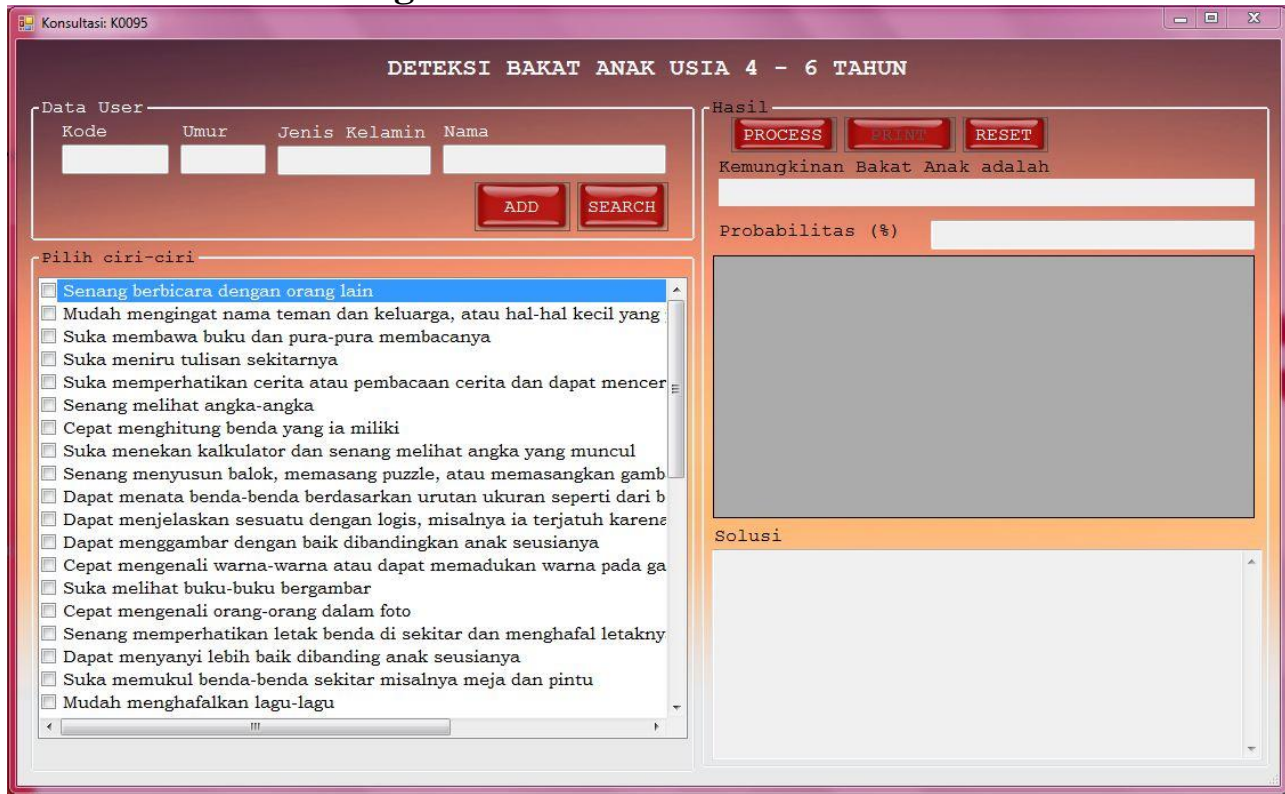

Gambar 3 Form Deteksi Bakat Anak 
4.3 Pengujian Sistem

\begin{tabular}{|c|c|c|c|c|}
\hline No & $\begin{array}{l}\text { Deskripsi } \\
\text { Kebutuhan }\end{array}$ & Cara Pengujian & Hasil Yang Diharapkan & Ket \\
\hline 1. & $\begin{array}{l}\text { Menguji validasi } \\
\text { login pakar atau } \\
\text { admin }\end{array}$ & $\begin{array}{l}\text { Pilih Menu Login lalu } \\
\text { masukan username dan } \\
\text { password kemudian tekan } \\
\text { tombol Login }\end{array}$ & $\begin{array}{l}\text { Jika password yang } \\
\text { dimasukan benar dan } \\
\text { menekan tombol login } \\
\text { maka menu-menu pada } \\
\text { halaman utama yang } \\
\text { tidak aktif akan menjadi } \\
\text { aktif dan bisa diklik }\end{array}$ & $\mathrm{OK}$ \\
\hline 2. & $\begin{array}{c}\text { Menguji } \\
\text { penambahan data } \\
\text { ciri-ciri }\end{array}$ & $\begin{array}{l}\text { Mengetikan nama ciri-ciri } \\
\text { dan tekan tombol save }\end{array}$ & $\begin{array}{l}\text { Data cirri-ciri berhasil } \\
\text { ditambahkan ke dalam } \\
\text { tabel data cirri-ciri dan } \\
\text { disimpan di database }\end{array}$ & $\mathrm{OK}$ \\
\hline 3. & $\begin{array}{c}\text { Menguji } \\
\text { perubahan data } \\
\text { ciri-ciri }\end{array}$ & $\begin{array}{l}\text { Mengklik ciri-ciri yang } \\
\text { akan diubah pada tabel } \\
\text { data ciri-ciri, kemudian } \\
\text { ketik nama ciri-ciri lalu } \\
\text { tekan tombol update }\end{array}$ & $\begin{array}{l}\text { Data ciri-ciri berhasil } \\
\text { diubah ke dalam tabel } \\
\text { data ciri-ciri dan } \\
\text { disimpan di database }\end{array}$ & $\mathrm{OK}$ \\
\hline 4. & $\begin{array}{l}\text { Menguji } \\
\text { penghapusan } \\
\text { data ciri-ciri }\end{array}$ & $\begin{array}{l}\text { Mengklik ciri-ciri yang } \\
\text { akan dihapus pada tabel } \\
\text { data ciri-ciri, kemudian } \\
\text { tekan tombol delete lalu } \\
\text { tekan yes }\end{array}$ & $\begin{array}{l}\text { Data ciri-ciri yang sudah } \\
\text { dihapus harus tidak ada } \\
\text { dalam tabel data ciri-ciri } \\
\text { dan database }\end{array}$ & OK \\
\hline 5. & $\begin{array}{c}\text { Menguji } \\
\text { penambahan data } \\
\text { bakat }\end{array}$ & $\begin{array}{l}\text { Mengetikan data nama } \\
\text { bakat, kemudian tekan } \\
\text { tombol save }\end{array}$ & $\begin{array}{l}\text { Data bakat berhasil } \\
\text { ditambahkan ke dalam } \\
\text { tabel data bakat dan } \\
\text { disimpan di database }\end{array}$ & $\mathrm{OK}$ \\
\hline 6. & $\begin{array}{c}\text { Menguji } \\
\text { perubahan data } \\
\text { bakat }\end{array}$ & $\begin{array}{l}\text { Mengklik bakat yang } \\
\text { akan diubah pada tabel } \\
\text { data bakat, kemudian } \\
\text { ketik nama bakat lalu } \\
\text { tekan tombol update }\end{array}$ & $\begin{array}{l}\text { Data bakat yang baru } \\
\text { berhasil diubah ke dalam } \\
\text { tabel data bakat dan } \\
\text { disimpan di database }\end{array}$ & $\mathrm{OK}$ \\
\hline 7. & $\begin{array}{c}\text { Menguji } \\
\text { penghapusan } \\
\text { data bakat }\end{array}$ & $\begin{array}{l}\text { Mengklik bakat yang } \\
\text { akan dihapus pada tabel }\end{array}$ & $\begin{array}{l}\text { Data bakat yang sudah } \\
\text { dihapus harus tidak ada }\end{array}$ & OK \\
\hline
\end{tabular}




\begin{tabular}{|c|c|c|c|c|}
\hline & & $\begin{array}{l}\text { data bakat, kemudian } \\
\text { tekan tombol delete }\end{array}$ & $\begin{array}{l}\text { dalam tabel bakat dan } \\
\text { database }\end{array}$ & \\
\hline 8. & $\begin{array}{c}\text { Menguji } \\
\text { penambahan data } \\
\text { aturan }\end{array}$ & $\begin{array}{l}\text { Pilih ciri-ciri dan bakat } \\
\text { kemudian masukkan } \\
\text { probabilitasnya lalu tekan } \\
\text { tombol save }\end{array}$ & $\begin{array}{l}\text { Data aturan berhasil } \\
\text { ditambahkan ke dalam } \\
\text { tabel aturan dan disimpan } \\
\text { di database }\end{array}$ & $\mathrm{OK}$ \\
\hline 9. & $\begin{array}{l}\text { Menguji } \\
\text { perubahan data } \\
\text { aturan }\end{array}$ & $\begin{array}{l}\text { Mengklik aturan yang } \\
\text { akan diubah pada tabel } \\
\text { aturan, kemudian pilih } \\
\text { ciri-ciri, bakat dan } \\
\text { masukkan probabilitas } \\
\text { lalu tekan tombol update }\end{array}$ & $\begin{array}{l}\text { Data turan berhasil } \\
\text { diubah ke dalam tabel } \\
\text { data aturan dan disimpan } \\
\text { di database }\end{array}$ & $\mathrm{OK}$ \\
\hline 10. & $\begin{array}{c}\text { Menguji } \\
\text { penghapusan } \\
\text { data aturan }\end{array}$ & $\begin{array}{l}\text { Mengklik aturan yang } \\
\text { akan dihapus pada tabel } \\
\text { data aturan, kemudian } \\
\text { tekan tombol delete }\end{array}$ & $\begin{array}{l}\text { Data turan yang sudah } \\
\text { dihapus harus tidak ada } \\
\text { dalam tabel turan dan } \\
\text { database }\end{array}$ & $\mathrm{OK}$ \\
\hline 11. & $\begin{array}{c}\text { Menguji } \\
\text { perhitungan hasil } \\
\text { deteksi }\end{array}$ & $\begin{array}{lcr}\text { Memilih ciri-ciri } & \text { yang } \\
\text { terdapat } & \text { pada } & \text { anak } \\
\text { kemudian } & \text { tekan tombol } \\
\text { process } & & \end{array}$ & $\begin{array}{l}\text { Hasil perhitungan bakat } \\
\text { anak dan keterangannya } \\
\text { berhasil ditampilkan }\end{array}$ & OK \\
\hline 12. & $\begin{array}{c}\text { Menguji } \\
\text { pencetakan hasil } \\
\text { deteksi }\end{array}$ & Menekan tombol print & $\begin{array}{l}\text { Menampilkan hasil } \\
\text { deteksi bakat sesuai } \\
\text { dengan data deteksi yang } \\
\text { telah dilakukan }\end{array}$ & $\mathrm{OK}$ \\
\hline 13. & $\begin{array}{c}\text { Menguji } \\
\text { pengulangan } \\
\text { deteksi }\end{array}$ & Menekan tombol reset & $\begin{array}{l}\text { Hasil deteksi yang telah } \\
\text { dilakukan sebelumnya } \\
\text { akan terhapus, dan dapat } \\
\text { melakukan deteksi yang } \\
\text { baru }\end{array}$ & OK \\
\hline 14. & $\begin{array}{l}\text { Menguji masuk } \\
\text { ke halaman } \\
\text { petunjuk }\end{array}$ & Mengklik menu petunjuk & $\begin{array}{l}\text { Berhasil masuk ke } \\
\text { halaman petunjuk }\end{array}$ & OK \\
\hline 15. & $\begin{array}{c}\text { Menguji } \\
\text { pengubahan } \\
\text { password login } \\
\text { pakar atau admin }\end{array}$ & $\begin{array}{l}\text { Memasukkan } \text { password } \\
\text { lama, lalu masukkan } \\
\text { password baru dan } \\
\text { konfirmasi password }\end{array}$ & $\begin{array}{l}\text { Password login akan } \\
\text { berubah dengan } \\
\text { password yang baru }\end{array}$ & OK \\
\hline
\end{tabular}




\begin{tabular}{|c|c|c|c|c|}
\hline & & $\begin{array}{l}\text { yang baru kemudian tekan } \\
\text { tombol change password }\end{array}$ & & \\
\hline 16. & $\begin{array}{l}\text { Menguji log out } \\
\text { pakar atau admin }\end{array}$ & Mengklik menu $\log$ out & $\begin{array}{l}\text { Menu-menu yang aktif } \\
\text { pada halaman utama } \\
\text { menjadi tidak aktif }\end{array}$ & $\mathrm{OK}$ \\
\hline 17. & $\begin{array}{l}\text { Menguji Validasi } \\
\text { inputan textbox } \\
\text { kosong pada } \\
\text { input data ciri- } \\
\text { ciri }\end{array}$ & $\begin{array}{l}\text { Tidak mengisi textbox } \\
\text { pada form data ciri-ciri }\end{array}$ & $\begin{array}{l}\text { Data parameter data ciri- } \\
\text { ciri dalam kondisi textbox } \\
\text { kosong tidak boleh } \\
\text { tersimpan kedalam tabel } \\
\text { data ciri-ciri dan muncul } \\
\text { peringatan bahwa data } \\
\text { belum lengkap. }\end{array}$ & $\mathrm{OK}$ \\
\hline 18. & $\begin{array}{lr}\text { Menguji } & \text { validasi } \\
\text { inputan } & \text { textbox } \\
\text { kosong } & \text { pada } \\
\text { input data bakat }\end{array}$ & $\begin{array}{l}\text { Tidak mengisi textbox } \\
\text { pada form data bakat }\end{array}$ & $\begin{array}{l}\text { Data parameter data } \\
\text { bakat dalam kondisi } \\
\text { textbox kosong tidak } \\
\text { boleh tersimpan kedalam } \\
\text { tabel data bakat dan } \\
\text { muncul peringatan } \\
\text { bahwa data belum } \\
\text { lengkap. }\end{array}$ & $\mathrm{OK}$ \\
\hline 19. & $\begin{array}{lr}\text { Menguji } & \\
\text { duplikasi } & \text { pada } \\
\text { aturan } & \text { sistem } \\
\text { pakar } & \end{array}$ & $\begin{array}{l}\text { Mengisi kombinasi aturan } \\
\text { ciri-ciri dan bakat dan klik } \\
\text { tombol save }\end{array}$ & $\begin{array}{l}\text { Data aturan tidak bisa di } \\
\text { save dan muncul } \\
\text { pemberiktahuan bahwa } \\
\text { kombinasi bakat dan ciri- } \\
\text { ciri aturan sudah ada. }\end{array}$ & $\mathrm{OK}$ \\
\hline 20. & $\begin{array}{l}\text { Menguji } \\
\text { autonumber kode } \\
\text { user }\end{array}$ & Mengisi data $u s e r$ & $\begin{array}{l}\text { Textbox kode muncul } \\
\text { dengan kode user yang } \\
\text { berurutan }\end{array}$ & OK \\
\hline
\end{tabular}

\section{KESIMPULAN DAN SARAN}

5.1 KESIMPULAN

Berdasarkan pembangunan sistem pakar yang telah dilakukan selama proses perencanaan hingga implementasi Sistem Pakar Deteksi Bakat Anak Usia 4 sampai dengan 6 Tahun Menggunakan Metode Teorema Bayes, maka dapat diambil kesimpulan sebagai berikut:

1. Dengan adanya sistem pakar ini dapat membantu orang tua dan guru mengenali bakat yang dimiliki oleh anak berdasarkan ciri-ciri yang 
terdapat pada anak dan dapat membimbing serta mengarahkan anak sesuai dengan bakat yang telah diketahui.

2. Sistem pakar ini memberikan pengetahuan kepada orang tua dan guru bahwa potensi kecerdasan anak tidak hanya dalam bidang akademik saja melainkan terdapat 8 kecerdasan majemuk sehingga orang tua dan guru dapat memperhatikan kecerdasan anak dari sisi selain akademik.

\subsection{SARAN}

Setelah melakukan penelitian dan pengerjaan Sistem Pakar Deteksi

Bakat Anak Usia 4 sampai dengan 6 Tahun Menggunakan Metode Teorema Bayes maka dapat diberikan beberapa saran untuk pengembangan sistem ini sebagai berikut:

1. Antarmuka (interface) sistem ini dapat dikembangkan menjadi lebih menarik.

2. Diharapkan sistem pakar ini dapat dikembangkan menjadi teknologi berbasis website atau mobile sehingga dapat dimanfaatkan oleh banyak orang dimana saja dan kapan saja.

3. Dalam penggunaan kedepan penting untuk memperhatikan dan mempertimbangkan tingkat keamanan (security) dari data-data sistem pakar, sehingga data-data pakar tidak dapat diubah oleh sembarang orang.

\section{DAFTAR PUSTAKA}

Bunda Lucy, Panduan Praktis Tes Minat dan Bakat Anak, Penebar Plus, 2016, Jakarta.

Hildayani Rini, dkk. Psikologi Perkembangan Anak, Penerbit Universitas Terbuka, 2006, Jakarta.

T.Sutojo; M. Edy; S. Vincen, Kecerdasan Buatan, Andi, 2011, Yogyakarta.

Wiyani Novan Ardy, Psikologi Perkembangan Anak Usia Dini Panduan bagi Orang Tua dan Pendidik PAUD dalam Memahami serta Mendidik Anak Usia Dini, Gava Media, 2014, Yogyakarta.

Agustina, Sistem Pakar Mendiagnosa Penyakit Kista Ovarium dengan Menggunakan Metode Bayes, 2014, Tersedia di: http://www.ilmuskripsi.com/2016/06/jurnal-sistem-pakar-mendiagnosa.html

[diunduh : 24 Februari 2017]

Anggara Ganda; P.Gede; W.Arif, Membangun Sistem Pakar Menggunakan Teorema Bayes Untuk Mendiagnosa Penyakit Paru-paru, 2016, Tersedia di: http://ojs.amikom.ac.id/index.php/semnasteknomedia/article/viewFile/1360/1336 [diunduh: 21 Februari 2017]

Ariandhi Sukma, Nugraha Danang Aditya, Sistem Pendukung Keputusan Untuk Mendeteksi Tipe Kecerdasan Anak Menggunakan Metode Fuzzy Logic, 2014, Tersedia di: http://ejournal.unikama.ac.id/index.php/JFTI/article/view/500/266 [diunduh:25 Februari 2017] Mariyana Rita, Kompetensi Guru Dalam Pembelajaran Berbasis Pendidikan Karakter Untuk Anak Usia Dini, 2014, Tersedia di: ejournal.upi.edu/index.php/pedagogia/article/viewFile/3296/2282 [ diunduh: 21 Februari 2017] 